\title{
Implementasi Rule Based Expert Systems untuk Realtime Monitoring Penyelesaian Perkara Pidana Menggunakan Teknologi Radio Frequency Identification
}

\author{
Marfuah* $^{*}$ \\ Fakultas Teknik Jurusan Teknik Informatika Universitas Universal
}

Naskah Diterima : 20 Februari 2016; Diterima Publikasi : 13 Mei 2017

DOI: 10.21456/vol7iss1pp73-79

\begin{abstract}
One of the problems in the criminal case completions is that the difficulty of making decision to estimate when the settlement of the case file will be fulfilled. It is caused by the number of case files handled and detention time changing. Therefore, the fast and accurate information is needed. The research aims to develop a monitoring system tracking and tracking of scheduling rules using Rule Based Expert Systems method with 17 rules, and supported by Radio Frequency Identification technology (RFID) in the form of computer applications. Based on the output of the system, an analysis is performed in the criminal case settlement process with a set of IF-THEN rules. The RFID reader read the data of case files through radio wave signals emitted by the antenna toward activeTag attached in the criminal case file. The system is designed to monitor the tracking and tracing of RFID-based scheduling rules in realtime way that was built in the form of computer application in accordance with the system design. This study results in no failure in reading active tags by the RFID reader to detect criminal case files that had been examined. There were many case files handled in three different location, they were the constabulary, prosecutor, and judges of district court and RFID was able to identify them simultaneously. So, RFID supports the implementation of Rule Based Expert Systems very much for realtime monitoring in criminal case accomplishment.
\end{abstract}

Keywords : Rule Based Expert system; Realtime monitoring; RFID; Criminal Case.

\begin{abstract}
Abstrak
Salah satu permasalahan dalam penyelesaian perkara pidana yaitu sulitnya dalam pengambilan keputusan untuk memperkirakan kapan penyelesaian berkas perkara akan selesai. Hal ini dikarenakan banyaknya berkas perkara yang ditangani serta waktu penahanan yang berubah-ubah. Oleh sebab itu perlu adanya informasi secara cepat dan akurat terhadap proses penyelesaian perkara pidana. Penelitian ini bertujuan mengembangan sistem monitoring pelacakan dan penelusuran penjadwalan aturan menggunakan metode Rule Based Expert Systems dengan 17 rule, serta didukung oleh teknologi Radio Frequency Identification (RFID) dalam bentuk aplikasi komputer. Berdasarkan output sistem, dilakukan analisis dalam proses penyelesaian perkara pidana dengan seperangkat aturan IF-THEN. Reader RFID melakukan pembacaan data berkas perkara pidana melalui sinyal gelombang radio yang dipancarkan oleh antena terhadap Tag aktif yang ditempel pada berkas perkara pidana. Hasil penelitian ini tidak ada kegagalan dalam pembacaan Tag aktif oleh Reader RFID untuk mendeteksi berkas perkara pidana yang telah diujikan. Banyaknya berkas perkara yang ditangani ditiga lokasi yaitu Kepolisian, Jaksa Penuntut Umum dan Hakim Pengadilan Negeri, teknologi RFID mampu melakukan identifikasi secara serentak dengan berkerja melalui frekuensi gelombang radio untuk proses Rule Based Expert Systems. Sehingga teknologi RFID sangat menunjang dalam implementasi Rule Based Expert Systems untuk realtime monitoring penyelesaian perkara pidana.
\end{abstract}

Keywords : Rule Based Expert Systems; Realtime Monitoring; RFID; Perkara Pidana.

\section{Pendahuluan}

Dalam bidang hukum, penyelesaian perkara pidana mempunyai alur penyelesaian perkara pidana dan batas waktu penahanan. Namun batas waktu tersebut tidak bisa ditentukan dikarenakan adanya perpanjangan waktu penahanan, akibatnya sulit untuk diprediksi kapan berkas perkaranya akan selesai (Marbun, 2011). Rule Based Expert Systems sangat berguna dalam mendeteksi pelanggaran waktu. Sehingga memiliki kontribusi penting terhadap sistem analisis waktu berbasis aturan realtime. Hukum merupakan aturan umum dari pertimbangan semua bukti-bukti yang ada.

\footnotetext{
*) Penulis korespondensi: marfuah916@gmail.com
} 
Jadi hukum dianggap sebagai seperangkat aturan, IF THEN menghasilkan basis pengetahuan. Sehingga dapat membantu dalam pengambilan keputusan. Pelacakan dan penelusuran penjadwalan aturan berbasis RFID, menghasilkan kinerja yang lebih baik dibandingkan dengan aturan penjadwalan tradisional, berkaitan dengan siklus waktu dan nilai informasi yang dihasilkan lebih akurat (Chongwatpol dan Ramesh, 2013).

Penelitian ini bertujuan mengembangan sistem monitoring pelacakan dan penelusuran penjadwalan aturan menggunakan metode Rule Based Expert Systems dengan 17 rule, serta didukung oleh teknologi Radio Frequency Identification (RFID) dalam bentuk aplikasi komputer. Sistem operasi realtime mampu melakukan pemantauan dan mengendalikan secara komplek. Sistem merespon perubahan secara cepat dalam tiap siklus waktu berdasarkan aturan yang ada pada sistem (Cheng, 1993). Dengan demikian implementasi Rule Based Expert Systems untuk realtime monitoring penyelesaian perkara pidana menggunakan teknologi RFID mampu memberikan kemudahan dalam melakukan monitoring waktu penyelesaian perkara pidana dan memprioritaskan perkara berdasarkan tingkat kesulitan penyelesaian perkara pidana, sehingga meningkatkan kinerja penyelesaian perkara pidana secara efektif pada bagian penyidik kepolisian, jaksa penuntut umum dan pengadilan negeri.

\section{Kerangka Teori}

\subsection{Rule Based Expert Systems}

Sistem pakar berbasis aturan menanamkan pola berdasarkan cara berpikir seorang pakar sehingga mampu mensimulasikan kerangka pola pikir dalam menyelesaikan suatu masalah (Hartati dan Sari, 2013). Struktur sistem pakar sebagaimana ditunjukkan Gambar 1.

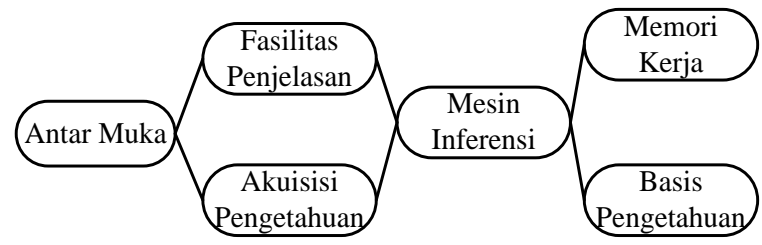

Gambar 1. Struktur sistem pakar (Hartati dan Sari, 2013)

Basis pengetahuan dan mesin inferensi merupakan komponen utama dalam sistem pakar, dimana basis pengetahuan berisi tentang fakta serta aturan mengenai suatu hal berdasarkan pola pikir seorang pakar. Sedangkan mesin inferensi bertugas untuk mencari atau menyesuaikan terhadap aturan-aturan yang digunakan sehingga mampu memberikan solusi sebagai pendukung pengambilan keputusan. Fasilitas penjelas memberikan penjelesan bagaimana solusi tersebut dihasilkan oleh sistem. Pengguna dapat berinteraksi terhadap sistem melalui antar muka sistem, dalam proses interaksi maka fakta-fakta yang dikonsultasikan sesuai dengan permasalahan akan disimpan di dalam memori kerja. Pengetahuan di dalam sistem dapat diperbaharui kapan saja pada akuisisi pengetahuan sesuai dengan perkembangan terhadap ruang lingkup permasalahan yang dihadapi. Graph pengetahuan sebagaimana ditunjukkan Gambar 2.

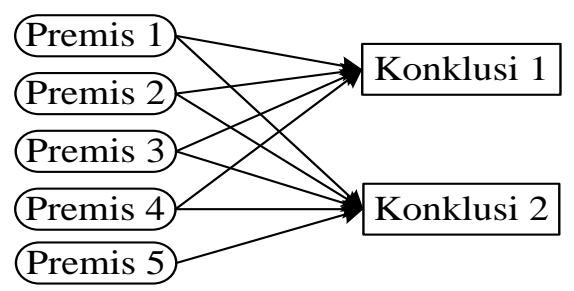

Gambar 2. Graph pengetahuan (Kusrini, 2008)

Keterangan :

Premis 1 : Waktu penyelesaian $>0$ sampai $<=30$ hari

Premis 2 : Ada saksi

Premis 3 : Ada tersangka

Premis 4 : Ada keterangan ahli

Premis 5 : Waktu penyelesaian $>30$ sampai $<=60$ hari

Konklusi 1 : Penyelesaian perkara mudah

Konklusi 2 : Penyelesaian perkara sedang

Berdasarkan Gambar 2.2 dijelaskan bahwa, jika premis 1 , premis 2 , premis 3 dan premis 4 maka konklusi 1. Sedangkan jika premis 1 , premis 2, premis 3 , premis 4 dan premis 5 maka konklusi 2. Dengan demikian diperlukan adanya proposisi, pernyataan yang bernilai benar atau salah. Proposisi yang dijadikan dasar kesimpulan merupakan premis, sedangakan konklusi hasil dari kesimpulan, berdasarkan sejumlah pernyataan yang dianggap benar maka akan disimpulkan sebuah pernyataan baru yang sebelumnya tidak diketahui. Dengan demikian premis mengarah pada fakta yang harus bernilai benar sebelum mendapatkan konklusi tertentu.

\subsection{Radio Frequency Identification (RFID)}

RFID berkerja melalui frekuensi gelombang radio untuk mengambil data pada tag yang kemudian ditransfer ke dalam sistem komputer dengan tiga komponen RFID yaitu reader, antena dan tag, yang mana antena mentrasfer sinyal melalui gelombang radio dan tag mentransmisikan data kembali ke antena (Hanan et al., 2011). Komponen RFID sebagaimana ditunjukkan Gambar 3.

RFID merupakan teknologi yang mampu melakukan identifikasi berbagai macam objek secara serentak berbasis gelombang radio, yang mana sensor RFID melakukan identifikasi tersebut dengan menggunakan frekuensi radio. Sensor RFID terbagi dua yakni 
transceiver (reader) dan transponder (tag) (Li dan Burcin, 2011).

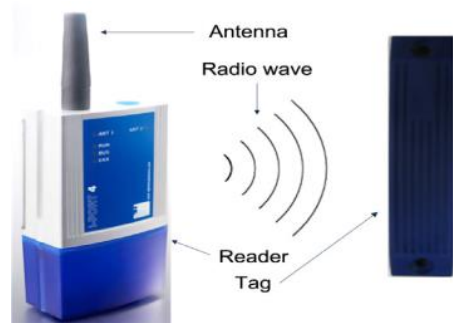

Gambar 3. Komponen RFID (Li dan Burcin, 2011)

Transceiver (reader) menanggapi perintah dari aplikasi perangkat lunak serta membaca data dari RFID tag. RFID Reader juga dapat dikatakan sebagai penghubung aplikasi perangkat lunak terhadap antena pemancar gelombang radio ke RFID tag, sehingga gelombang radio yang dipancarkan antena menyebar pada ruang sekitar. Oleh karena itu data dapat berpindah secara wireless ke RFID tag yang berada berdekatan dengan antena, data yang didapat oleh RFID Reader diolah oleh mikrokontroler yang terdapat pada RFID Reader (Li dan Burcin, 2011).

Transponder (tag) merupakan perangkat yang terdiri dari rangkaian elektronik yang mana didalamnya terintegrasi dengan antena, serta mempunyai memori untuk menyimpan data. Data yang tersimpan pada tiap RFID tag berbeda-beda seperti serial number yang bersifat read only karena merupakan data identitas RFID tag serta mampu menulis dan membaca secara berulang-ulang (Oztaysi et al., 2009).

Dalam implementasi Rule Based Expert Systems untuk realtime monitoring penyelesaian perkara pidana menggunakan teknologi RFID, tag ditempel pada berkas perkara dengan serial number yang menyimpan data object related dan lainnya, kemudian mengirimkan data ke RFID Reader sesuai permintaan. RFID reader diletakkan pada ruang penanganan perkara pada pihak kepolisian, jaksa penuntut umun dan hakim pengadilan negeri.

\subsection{Penyelesaian Perkara Pidana}

Hukum pidana merupakan aturan hukum mengenai pelanggaran dan kejahatan yang berdampak terhadap sosial (Soharto dan Jonaedi, 2013). Pelanggaran merupakan tindak pidana dengan ancaman ringan seperti denda atau kurungan sedangkan kejahatan sebaliknya ancaman bukan hanya denda atau kurungan tetapi juga hukuman mati dan penyitaan barang-barang, pencabutan hak dan pengumuman pengadilan. Dalam penelitian ini membahas mengenai hukum pidana kejahatan.

Untuk menjatuhkan suatu hukuman terhadap suatu tindak pidana maka sebelumnya diperlukan suatu rangkaian proses penyelesaian perkara. Alur penyelesaian perkara pidana sebagaimana ditunjukkan Gambar 4.

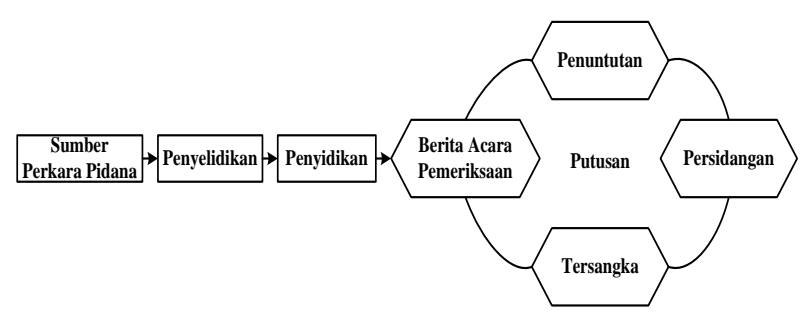

Gambar 4. Alur penyelesaian perkara pidana (Suharto dan Jonaedi, 2013)

Berdasarkan Gambar 4 pada KUHAP No. 8 dapat dijelaskan sebagai berikut :

1. Penyelidikan pasal 1 ayat (5) merupakan serangkaian tindakan penyelidik untuk mencari dan menemukan suatu peristiwa yang diduga sebagai tindak pidana guna menentukan dapat atau tidaknyadilakukan penyidikan menurut cara yang diatur dalam undang-undang hukum pidana.

2. Penyididkan pasal 1 ayat (2) adalah serangkaian tindakan penyidik dalam hal dan menurut cara yang diatur dalam undang-undang hukum pidana untuk mencari serta mengumpulkan bukti yang dengan bukti itu membuat terang tentang tindak pidana yang terjadi dan guna menemukan tersangkanya.

3. Berita Acara Pemeriksaan (BAP), diatur dalam pasal 75 ayat (1). Berita acara dibuat untuk setiap tindakan, pemeriksaan tersangka, penangkapan, penahanan, penggeledahan, pemasukan rumah, penyitaan benda, pemeriksaan surat, pemeriksaan saksi, pemeriksaan ditempat kejadian, pelaksanaan penetapan dan putusan pengadilan.

4. Tersangka pasal 1 ayat (14) adalah seorang yang karena perbuatanya atau keadaanya, berdasarkan bukti permulaan patut diduga sebagai pelaku tindak pidana.

5. Penuntutan pasal 1 ayat (7) merupakan tindakan penuntut umum untuk melimpahkan perkara pidana ke pengadilan negeri yang berwenang dalam hal dan menurut cara yang diatur dalam undang-undang hukum pidana dengan permintaan supaya diperiksa dan diputus oleh hakim di sidang pengadilan.

6. Persidangan merupakan suatu proses dimana keadilan dan kebenaran dipertaruhkan. Pengadilan menjadi benteng terakhir dalam mencari keadilan.

7. Putusan pengadilan pasal 1 ayat (11) adalah pernyataan hakim yang diucapkan dalam sidang pengadilan terbuka yang dapat berupa pemindaan atau bebas atau lepas dari segala tuntutan hukum dalam hal serta menurut cara yang diatur dalam undang-undang hukum pidana.

\section{Metode}

\subsection{Bahan dan Alat Peneliti}

Bahan penelitian yang digunakan adalah data yang diperoleh dari lapangan, berupa dokumen dan data dari pakar sesuai dengan informasi yang dibutuhkan dalam 
sistem penyelesaian perkara pidana. Kemudian data yang diperoleh dari berbagai sumber penelitian yang telah ada seperti buku, laporan, jurnal dan sebagainya.

Untuk membantu pembuatan dan pengujian implementasi Rule Based Expert Systems untuk realtime monitoring penyelesaian perkara pidana menggunakan teknologi RFID diperlukan alat penelitian seperti Prosesor Pentium Dual, RAM 1 GB, Harddisk 320 GB, Reader PF5210 Frekuensi 433.9 MHz dan RFID Tags PFH300. Adapun Perangkat lunak yang diperlukan adalah Windows XP, bahasa pemograman Visual Basic 6.0, XAMPP control panel application 2.3, SQL yog Enterprise 8.05, Active reports professional 2.0 dan Open Database Connectivity (ODBC) 5.1 .

\subsection{Prosedur penelitian}

Adapun prosedur penelitian yang harus dilalui dalam penelitian sebagaimana ditunjukkan Gambar 5 :

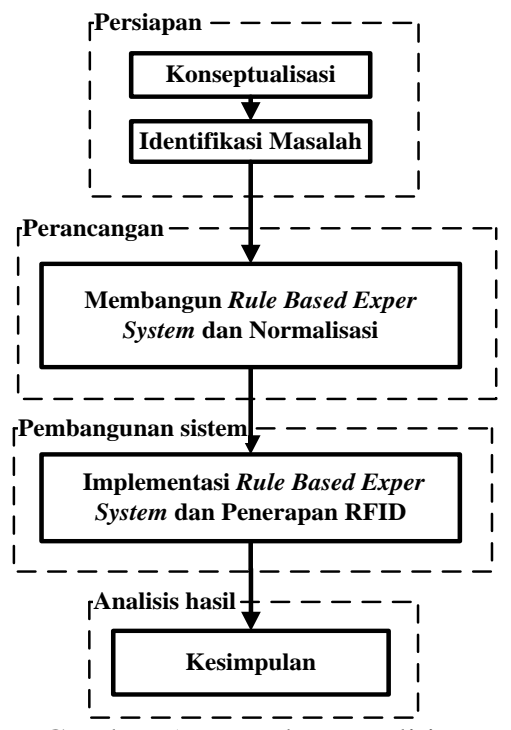

Gambar 5. Prosedur Penelitian

Berdasarkan Gambar 5 dapat dijelaskan sebagai berikut:

1. Tahap persiapan

Adapun hal-hal yang dilakukan dalam tahap persiapan sebagai berikut :

a. Konseptualisasi

Melakukan pengumpulan data-data untuk mendapatkan teori dan informasi melalui pakar, literatur, jurnal, artikel, situs internet, buku dan karya-karya ilmiah yang telah teruji kebenarannya mengenai implementasi Rule Based Expert Systems untuk realtime monitoring penyelesaian perkara pidana menggunakan teknologi RFID.

b. Identifikasi masalah

Mengidentifikasi permasalahan yang dihadapi khususnya dalam realtime monitoring penyelesaian perkara pidana dengan mengimplementasikan Rule
Based Expert Systems menggunakan teknologi RFID

2. Tahap perancangan

Pada tahap perancangan berdasarkan data-data yang telah diperoleh pada tahap persiapan selanjutnya membangun aturan-aturan yang dibutuhkan kemudian melakukan normalisasi untuk diimplementasikan kedalam sistem.

a. Membangun Rule Based Expert Systems

Rule Based Expert Systems yang terbagi 4 yaitu rule prioritas perkara pidana di Kepolisian, rule penyelesaian berkas perkara di Kepolisian, rule penyelesaian berkas perkara di Jaksa Penuntut Umum dan rule penyelesaian berkas perkara pada Hakim Pengadilan Negeri.

Rule prioritas penyelesaian perkara pidana Kepolisian R-01 hingga R-19, terdapat 4 konklusi dari aturan-aturan tersebut. Rule prioritas penyelesaian perkara pidana sebagaimana ditunjukkan pada Tabel 1 .

Tabel 1 Rule prioritas perkara pidana

\begin{tabular}{|c|c|}
\hline Kode & Rule \\
\hline R-01 & Waktu penyelesaian $>=0$ sampai $<=30$ hari \\
\hline $\mathrm{R}-02$ & Ada saksi \\
\hline $\mathrm{R}-03$ & Ada tersangka \\
\hline $\mathrm{R}-04$ & Ada keterangan ahli \\
\hline $\mathrm{R}-05$ & $\begin{array}{l}\text { Waktu penyelesaian }>30 \text { hari sampai }<=60 \\
\text { hari }\end{array}$ \\
\hline $\mathrm{R}-06$ & Ada penangkapan \\
\hline $\mathrm{R}-07$ & Ada penahanan \\
\hline $\mathrm{R}-08$ & Ada penyitaan \\
\hline R-09 & Ada penggeledahan \\
\hline $\mathrm{R}-10$ & $\begin{array}{l}\text { Waktu penyelesaian }>60 \text { hari sampai }<=90 \\
\text { hari }\end{array}$ \\
\hline $\mathrm{R}-11$ & $\begin{array}{l}\text { Waktu penyelesaian }>90 \text { hari sampai }<=120 \\
\text { hari }\end{array}$ \\
\hline $\mathrm{R}-12$ & Atensi Presiden atau pejabat pemerintah \\
\hline $\mathrm{R}-13$ & $\begin{array}{l}\text { Atensi pimpinan Kepolisian Republik } \\
\text { Indonesia (POLRI) }\end{array}$ \\
\hline $\mathrm{R}-14$ & Perhatian publik secara luas \\
\hline $\mathrm{R}-15$ & $\begin{array}{l}\text { Melibatkan tokoh formal atau informal yang } \\
\text { berdampak massal }\end{array}$ \\
\hline R-16 & $\begin{array}{l}\text { Berada pada hukum perdata dan hukum } \\
\text { pidana }\end{array}$ \\
\hline $\mathrm{R}-17$ & $\begin{array}{l}\text { Mencakup beberapa peraturan perundang- } \\
\text { undangan yang tumpang tindih }\end{array}$ \\
\hline $\mathrm{R}-18$ & $\begin{array}{l}\text { Penanganannya mengakibatkan dampak } \\
\text { nasional di bidang idiologi, politik, ekonomi, } \\
\text { sosial, budaya, agama atau keamanan }\end{array}$ \\
\hline $\mathrm{R}-19$ & $\begin{array}{l}\text { Penanganannya berkemungkinan } \\
\text { menimbulkan reaksi massal }\end{array}$ \\
\hline
\end{tabular}

Berikut ini merupakan aturan R-20 hingga R-23. Aturan-aturan ini bekerja dalam realtime monitoring 
penyelesaian berkas perkara pidana di Kepolisian. sebagaimana ditunjukkan pada Tabel 2.

Tabel 2 Rule penyelesaian perkara pidana Kepolisian

\begin{tabular}{ll}
\hline Kode & \multicolumn{1}{c}{ Rule } \\
\hline R-20 & Waktu penahanan $>=0$ sampai $<=20$ hari \\
R-21 & Waktu penahanan $>20$ hari sampai $<=60$ hari \\
R-22 & Waktu penahanan $>60$ hari sampai $<=120$ hari \\
R-23 & Waktu penahanan $>120$ hari \\
\hline
\end{tabular}

Selanjutnya yaitu rule penyelesaian perkara pidana oleh Jaksa Penuntut Umum mulai dari R-24 hingga R28. R-24 dan R-25 merupakan aturan untuk proses pemeriksaan berkas perkara pelimpahan tahap 1 . R-26 hingga R-28 merupakan aturan-aturan penahanan oleh Jaksa Penuntut Umum. Rule penyelesaian perkara pidana Jaksa Penuntut Umum sebagaimana ditunjukkan pada Tabel 3.

Tabel 3 Rule penyelesaian perkara pidana oleh Jaksa Penuntut Umum

\begin{tabular}{|c|c|}
\hline Kode & Rule \\
\hline $\mathrm{R}-24$ & Waktu pemeriksaan JPU $>=0$ sampai $<=6$ hari \\
\hline $\mathrm{R}-25$ & $\begin{array}{l}\text { Waktu pemeriksaan JPU > } 6 \text { hari sampai }<=14 \\
\text { hari }\end{array}$ \\
\hline $\mathrm{R}-26$ & $\begin{array}{l}\text { Waktu pemeriksaan JPU >14 hari sampai }<=34 \\
\text { hari }\end{array}$ \\
\hline R-27 & Waktu penahanan $>34$ hari sampai $<=124$ hari \\
\hline $\mathrm{R}-28$ & Waktu penahanan $>124$ hari \\
\hline
\end{tabular}

Berikut ini R-29 hingga R-32 merupakan rule realtime monitoring penyelesaian perkara pidana oleh Hakim Pengadilan Negeri hingga putusan perkara pidana. Rule penyelesaian perkara pidana Hakim Pengadilan Negeri sebagaimana ditunjukkan pada Tabel 4.

Tabel 4. Rule penyelesaian perkara pidana oleh Hakim Pengadilan Negeri

\begin{tabular}{ll}
\hline Kode & \multicolumn{1}{c}{ Rule } \\
\hline R-29 & Waktu penahanan $>=0$ sampai $<=30$ hari \\
R-30 & Waktu penahanan $>30$ hari sampai $<=90$ hari \\
R-31 & Waktu penahanan $>90$ hari sampai $<=150$ hari \\
R-32 & Waktu penahanan $>150$ hari
\end{tabular}

Berdasarkan Tabel 1, 2, 3 dan 4 Rule prioritas penyelesaian perkara pidana, terdapat beberapa konklusi dari aturan-aturan tersebut. Konklusi rule prioritas perkara pidana sebagaimana ditunjukkan pada Tabel 5.

b. Normalisasi

Berdasarkan data-data yang telah diperoleh pada tahap sebelumnya, selanjutnya dilakukan identifikasi terhadap data-data yang dibutuhkan dalam proses normalisasi untuk menghindari terjadinya redundansi data. Proses normalisasi untuk menormalkan tabel data yang dibuat dalam beberapa turunan tabel, mulai dari tabel Unnormalized Form, First Normal Form (INF) dan Second Normal Form (2NF) hingga tabel dianggap normal tidak ada anomaly.

Tabel 5. Konklusi rule penyelesaian perkara pidana

\begin{tabular}{|c|c|c|}
\hline Kode & Konklusi & Lokasi \\
\hline $\mathrm{K}-01$ & Penyelesaian perkara mudah & Kepolisian \\
\hline K-02 & Penyelesaian perkara sedang & Kepolisian \\
\hline K-03 & Penyelesaian perkara sulit & Kepolisian \\
\hline K-04 & $\begin{array}{l}\text { Penyelesaian perkara sangat } \\
\text { sulit }\end{array}$ & Kepolisian \\
\hline K-05 & Proses penyidikan & Kepolisian \\
\hline K-06 & $\begin{array}{l}\text { Proses penyidikan } \\
\text { diperpanjang maksimal } 40 \text { hari } \\
\text { oleh Jaksa Penuntut Umum }\end{array}$ & Kepolisian \\
\hline K-07 & $\begin{array}{l}\text { Proses penyidikan } \\
\text { diperpanjang maksimal } 30 \text { hari } \\
\text { oleh Ketua Pengadilan Negeri }\end{array}$ & Kepolisian \\
\hline K-08 & Tahanan keluar demi hukum & Kepolisian \\
\hline K-09 & $\begin{array}{l}\text { Pemeriksaan berkas } \\
\text { pelimpahan tahap } 1\end{array}$ & JPU \\
\hline $\mathrm{K}-10$ & Menunggu pemberitahuan $\mathrm{P} 21$ & JPU \\
\hline K-11 & $\begin{array}{l}\text { Pelimpahan tahap } 2 \text { ke JPU } \\
\text { serta proses penuntutan }\end{array}$ & JPU \\
\hline $\mathrm{K}-12$ & $\begin{array}{l}\text { Proses penuntutan } \\
\text { diperpanjang maksimal } 30 \text { hari } \\
\text { oleh Ketua Pengadilan Negeri }\end{array}$ & JPU \\
\hline $\mathrm{K}-13$ & Tahanan keluar demi hukum & JPU \\
\hline K-14 & Proses persidangan & $\mathrm{PN}$ \\
\hline K-15 & $\begin{array}{l}\text { Proses persidangan } \\
\text { diperpanjang maksimal } 60 \text { hari } \\
\text { oleh Ketua Pengadilan Negeri }\end{array}$ & $\mathrm{PN}$ \\
\hline $\mathrm{K}-16$ & $\begin{array}{l}\text { Proses persidangan } \\
\text { diperpanjang maksimal } 30 \text { hari } \\
\text { oleh Ketua Pengadilan Tinggi }\end{array}$ & $\mathrm{PN}$ \\
\hline K-17 & Tahanan keluar demi hukum & $\mathrm{PN}$ \\
\hline $\mathrm{K}-18$ & Putusan perkara & $\mathrm{PN}$ \\
\hline
\end{tabular}

4. Pembangunan sistem

Pada tahapan ini implementasi Rule Based Expert Systems untuk realtime monitoring penyelesaian perkara pidana menggunakan teknologi RFID, dibangun dalam bentuk aplikasi komputer sesuai dengan pola rancangan sistem. Secara menyeluruh rancangan sistem digambarkan dalam sebuah kerangka sistem dengan menggunakan metode ilmiah. Kerangka implementasi Rule Based Expert Systems untuk realtime monitoring penyelesaian perkara pidana dengan menggunakan teknologi RFID sebagaimana ditunjukkan Gambar 6 .

Berdasarkan Gambar 6 dapat dijelaskan bahwa untuk melakukan perhitungan waktu penyelesaian perkara pidana berdasarkan pada tanggal masuknya 
berkas perkara pada bagian Kepolisian, Jaksa Penuntut Umum dan Hakim Pengadilan Negeri dengan menggunakan teknologi RFID.

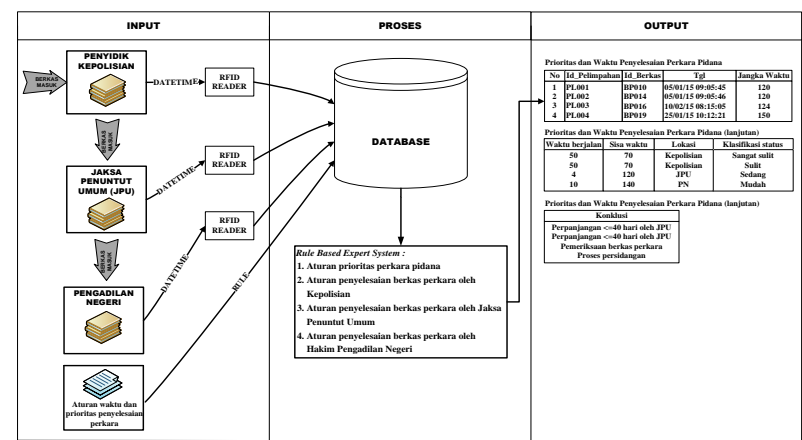

Gambar 6. Kerangka sistem penyelesaian perkara

Waktu penyelesaian berkas perkara dikurangkan dengan waktu yang telah berjalan dalam proses penyelesaian perkara pidana. Sistem bekerja berdasarkan rule yang ada untuk menghasilkan status proses berkas perkara. Kemudian diimplementasikan dalam suatu sistem komputer. Form input Rule Based Expert Systems sebagaimana ditunjukkan Gambar 7.

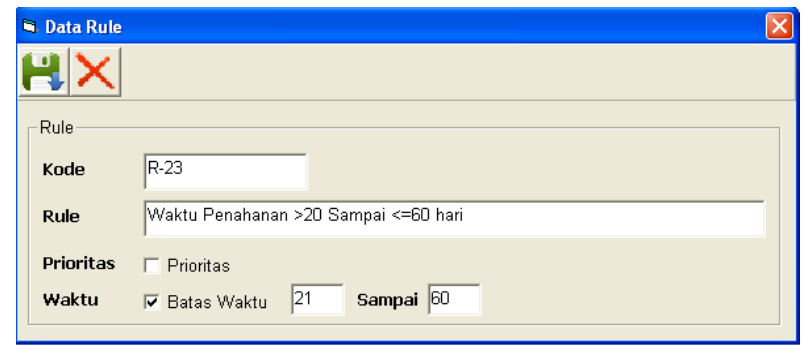

Gambar 7. Form input Rule Based Expert Systems

Berikut ini merupakan form input mulai dari input berkas, kerelasian berkas_d, berkas_rule dan berkas_perkara. Form input data-data berkas sebagaimana ditunjukkan Gambar 8.

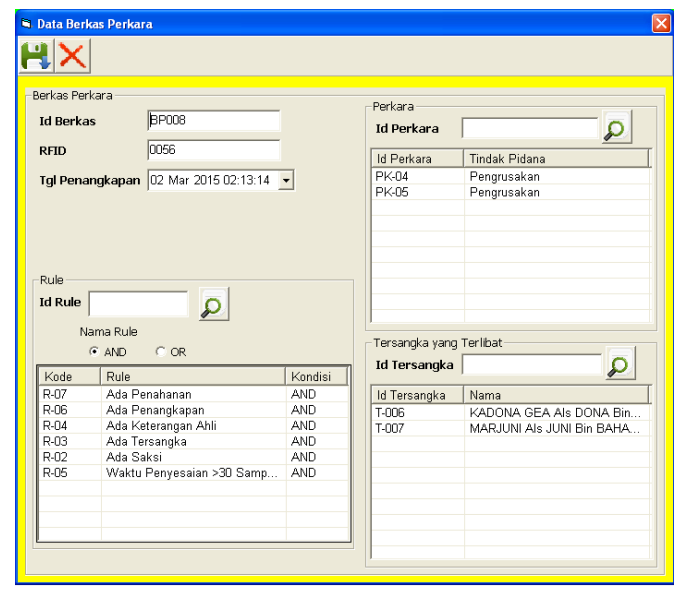

Gambar 8. Form input data-data berkas
Adapun output dari implementasi rule based expert Systems menggunakan teknologi RFID untuk realtime monitoring penyelesaian perkara pidana. Informasi yang diberikan yaitu prioritas perkara, status lokasi, status proses berkas perkara dan perhitungan berdasarkan waktu penyelesaian berkas perkara. Output rule based expert Systems sebagaimana ditunjukkan Gambar 9.

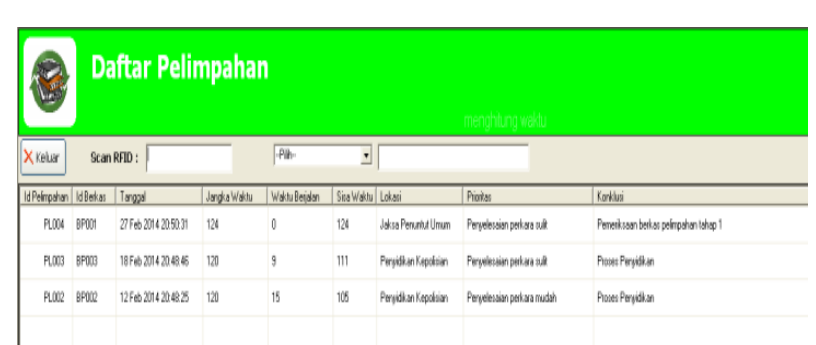

Gambar 9. Output Rule Based Expert Systems

5. Tahap analisis hasil

Tahap analisis hasil melakukan simulasi terhadap proses implementasi Rule Based Expert Systems untuk realtime monitoring penyelesaian perkara pidana menggunakan teknologi RFID dengan menganalisis 17 rule penyelesaian berkas perkara pidana terhadap sample yang digunakan untuk memperoleh kesimpulan hasil penelitian.

\section{Hasil dan Pembahasan}

Implementasi Rule Based Expert Systems untuk realtime monitoring penyelesaian perkara pidana menggunakan teknologi RFID. Melakukan monitoring waktu penyelesaian perkara pidana, prioritas perkara, status keberadaaan berkas perkara dan status proses berkas perkara. Monitoring waktu penyelesaian berkas perkara memberikan informasi waktu berjalan terhadap proses penyelesaian perkara. Mulai dari penahanan yang telah dilakukan oleh Kepolisian, hingga berkas dilimpahkan kepada pihak Jaksa Penuntut Umum dan Hakim Pengadilan Negeri dengan menggunakan teknologi RFID.

Rule Based Expert Systems untuk prioritas perkara mampu membantu pihak kepolisian dalam pengambilan keputusan untuk memprioritaskan penanganan perkara. Kemudian status proses perkara merupakan informasi mengenai langkah apa yang sedang dilakukan terhadap berkas perkara pidana tersebut berdasarkan waktu berjalan selama proses penyelesaian berkas perkara, dimana 1 hari adalah 24 jam. Sedangkan status keberadaan berkas perkara dapat diketahui dengan pelimpahan yang sedang dilakukan dengan menggunakan teknologi RFID. Sehingga sistem secara transparan mampu memberikan informasi secara umum kepada masyarakat mengenai penanganan perkara pidana. Serta meningkatkan kinerja pihak Kepolisian, Jaksa Penuntut Umum dan Hakim Pengadilan Negeri dalam menangani berkas perkara dengan informasi realtime monitoring penyelesaian perkara pidana. 
Penelitian ini menggunakan 17 rule penyelesaian berkas perkara pidana. Hasil penelitian tidak ada kegagalan dalam pembacaan Tag aktif oleh Reader RFID. Teknologi RFID mampu digunakan dalam implementasi Rule Based Expert Systems untuk realtime monitoring penyelesaian perkara pidana, sebagaimana hasil pengujian sistem.

Sedangkan pada penelitian sebelumnya mengenai sistem monitoring secara realtime menggunakan teknologi RFID yang digunakan pada ruang bedah. Sistem ini melakukan pendeteksian terhadap tim bedah serta waktu perpindahan posisi pada saat proses bedah berlangsung. Waktu deteksi perubahan posisi $80 \%$ antara 30-60 detik. Semakin banyak perubahan posisi dilakukan secara bersamaan maka semakin lama waktu deteksi RFID. Serta tidak ada kegagalan dalam pembacaan Transponder (Tag) aktif oleh Transceiver (Reader) RFID (Kranzfelder et al., 2012).

\section{Kesimpulan}

Implementasi Rule Based Expert Systems mampu memberikan kemudahan dalam monitoring penyelesaian perkara pidana berdasarkan 17 rule yang digunakan. Sehingga mempermudah dalam memberikan informasi mengenai proses penyelesaian perkara pidana sesuai dengan fakta yang ada. Teknologi RFID mampu digunakan dalam implementasi Rule Based Expert Systems untuk realtime monitoring penyelesaian perkara pidana dengan tidak ada kegagalan dalam pembacaan Tag aktif oleh Reader RFID.

\section{Daftar Pustaka}

Cheng, A.M.K., Browne, J.C., Mok, A.K., dan Wang, R.H., 1993. Analysis of Realtime Rule Based Systemss with Behavioral Constraint Assertions Specified in Estella, IEEE Transactions on Software Engineering, vol. 19, 863-885.
Chongwatpol, J., dan Ramesh, S., 2013. RFID Enabled Track And Traceability in Job Shop Scheduling Environment, European Journal of Operational Research 227, 453-463.

Dewan Perwakilan RI., 1981. Undang-Undang No. 8 tentang Hukum Acara Pidana (KUHAP), CV. Maya Sari Solo.

Hanan, M.A., Maher, A., R.A. Begum., dan Hassan, B., 2011. Radio Frequency Identification (RFID) and Communication Technologies For Solid Waste Bin and Truck Monitoring Systems, Waste Management 31, 2406-2413.

Hartati, S., dan Sari, I., 2013. Sistem Pakar dan Pengembangannya, Graha Ilmu Yogyakarta.

Kepala Kpolisian RI., 2009. PERKAP RI No. 12 tentang Pngawasan dan Pengendalian Penanganan Perkara Pidana di Lingkungan Kepolisisan Negara Republik Indonesia.

Kusrini., 008. Aplikasi Sistem Pakar Menentukan Faktor epastian Pengguna dengan Metode Kuantifikasi Pertanyaan, Andi Yogyakarta.

Kranzfelde, M., Dorit, Z., Thomas, J.,Armin, S., Sonja, G., Helmut, F., dan Hubertus, F., 2012. Realtime Monitoring for Detection of Retained Surgical Sponges and Motion in the Surgical Operation Room Using Radio-Frequency Identification (RFID) Technology A Preclinical Evaluation, Journal of Surgical Research 175, 191-198.

Li, N., dan Burcin, B.G., 2011. Performance Based Evaluation of RFID Based Indoor Location Sensing Solutions For The Built Environment, Advanced Engineering Informatics 25, 535-546.

Marbun, R., 2011. Kiat Jitu Menyelesaikan Kasus Hukum, Visimedia Jakarta.

Oztaysi, B., Serdar, B., dan Farma, A., 2009. Radio Frequency Identification (RFID) in Hospitality, Technovation 29, 618-624.

Suharto., dan Jonaedi, E., 2013. Panduan Praktis Bila Anda Menghadapai Perkara Pidana Mulai Proses Penyelidikan Hingga Persidangan, Kencana Prenadamedia Group Jakarta. 